International Journal of English Literature and Social Sciences
Vol-6, Issue-3; May-Jun, 2021

\title{
Women in Sudha Murty's Short Stories
}

Peer-Reviewed Journal

\author{
Disha Esther Ramtek
}

Former Assistant Professor, St. Aloysius Institute of Technology, and Guest Lecturer, Kalaniketan Polytechnic College, Madhya Pradesh, India

Received: 12 Apr 2021; Received in revised form: 03 May 2021; Accepted: 25 May 2021; Available online: 14 Jun 2021

(C)2021 The Author(s). Published by Infogain Publication. This is an open access article under the CC BY license

(https://creativecommons.org/licenses/by/4.0/).

\begin{abstract}
Sudha Murty is an Indian writer who writes in both Kannada and English language. Her books are loved by young and adults, and have been translated in many other Indian languages. This research paper focuses on women in the short stories by Sudha Murty with special reference to her first book for children in English, How I Taught My Grandmother to Read and Other Stories. In the short stories Sudha writes about the women who have impacted her life in various ways. The women in the stories stand as an example of the roles that are usually played by most of the women and also describe issues faced by them. Not only does she write about the problems that a woman faces, but how a woman has the strength to make a difference in her own life and in the lives of others. This paper looks at the women characters in the light of their role in inculcating values, importance of education in their lives, problems of gender inequality and infertility.
\end{abstract}

Keywords - Sudha Murty, Women, Short Stories, Indian Writing in English, Children's Book.

\section{INTRODUCTION}

\section{Indian Writing in English}

Indian Writing in English is a reference to the body of works written in English language by writers residing in India or writers who were born in India but residing elsewhere. The native or co-native language of these writers could be one of numerous languages of India.

At the onset of the sixteenth century British started to establish their trade posts in India. Subsequently British started ruling India and under this rule on 2 February 1835, Thomas Babington Macaulay presented his 'Minute on Indian Education' which aimed at establishment of teaching a Western curriculum with English language as the medium of instruction. By the end of eighteenth and the beginning of the nineteenth century the establishment of English education in the cities of Madras, Bombay and Calcutta led to the emergence of Indian literature in English.

Both Indians who got English education in India and the ones who acquired knowledge of English language during their stay or education in foreign nations began to use this language to express themselves. In 1793, Sake
Dean Mahomed wrote a book called The Travels of Dean Mahomed, which is considered to be the first book written by an Indian in English. Kashiprasad Ghoshbecame thefirst Indian poet who worked in English, his written shayaris and other poems were published in 1830. Bankim Chandra Chattopadhyay's Rajmohan's Wife, published in 1864 is the first Indian novel written in English. Sochee Chunder Dutt was the first writer of fiction. From Micheal Madhusudan Dutt, Rabindranath Tagore, Raja Ram Mohan Roy, Mulk Raj Anand, to name a few from preindependent India to Salman Rushdie, Vikram Seth, Arundhati Roy, Jhumpa Lahiri, in post-independent India. The list of Indian writers in English is long and still continues to increase.

Evidently, Indian writers in English including poets, novelists, essayists, and dramatists have been making significant contributions to the world literature since pre - Independence era, especially past few years have seen immense growth and vibrancy in Indian English Literature with wide range of themes been dealt by the writers. 


\section{Sudha Murty}

Sudha Murty was born on August 19, 1950 in Shiggaon, Karnataka. A graduate in Electrical and Electronics Engineering from B.V. Bhoomaraddi College of Engineering and Technology (BVBCET), which is presently known as KLE Technological University (KLE Tech). She completed her post-graduation in Computer Science from the Indian Institute of Science. She is the chairperson of the Infosys Foundation since its inception in December 1996, a visiting Professor at Bangalore University, best known for her social work and as an Indian writer.

As an author she excels in Kannada and English language. With 17 books in Kannada and 23 books in English language under her name. Her works include novels, travelogues, technical books, collections of short stories and non-fiction pieces. She has gained love and admiration as a children's author with her books like How I Taught My Grandmother to Read and Other Stories, The Gopi Diaries: Coming Home, Grandma's Bag of Stories. Her works are included as course material in schools which show that she has written educational works and has taught the real meaning of life to children and youth both. Her stories tell that very naturally and emotionally (Vaswani, 2021).

She received the R. K. Narayan Award for Literature and the Padma Shri in 2006; the Daana Chintamani Attimabbe Award from the government of Karnataka for excellence in Kannada literature in 2011 and Lifetime Achievement Award at the 2018 Crossword Book Awards. Apart from these she is a recipient of many other prizes and awards for her academic, literary, social contribution and excellence. In addition to these she has received seven honorary doctorates from some of India's top universities.

Overall writing of Sudha Murty deals with the education, religious tasks, cultural aspects, family relationship, social attitudes, economic situation, feminist problems, etc. Sudha Murty's writing is the mirror of society where the picture of the Indian women in all walks of life political, social, educational, architectural, administrative, and domestic is clearly shown and the prolific writer deals with all aspects of society (Kangne\&Lahane, 2016).

\section{Representation of Women in Sudha Murty'sHow I Taught My Grandmother to Read and Other Stories}

Sudha Murty's writings have mostly an autobiographical touch. And especially when it comes to writing for children, she loves to share her experiences with the younger generation. In one of her interviews with Times of India, Sudha mentioned, "For imagination, the sky is the limit but the reality is far more unimaginable and that is why I like writing non-fiction. From fiction, you do not get to learn much because it is only imagination. Whereas, from non-fiction, people can understand and learn from the realities it covers."

How I Taught My Grandmother to Read and Other Stories is Sudha Murty's first book for children, published in 2004. The book consists of stories from her own experiences, weaved with the instruments of storytelling, all of which have taught her something. This book consists of twenty-four short stories, but for the purpose of study of this research paper only seven short stories are considered, namely, 'How I Taught My Grandmother to Read', 'The Red Rice Granary', 'Real Jewels', ‘Appro J.R.D.', 'The Rainy Day', 'Gowramma’s Letter' and ' $A$ ' for Honesty'.

Sudha has always been vocal about women's rights and gender equality, most of her books portray woman in the glory of her simplicity and strength. A woman plays numerous roles throughout her life, while facing the challenges posed by society. In the delightful short stories from the book, How I Taught My Grandmother to Read and Other Stories, Sudha skillfully brings out the struggles of a woman and the significant roles played by her which not just impacts her life, her family but the society at large.

\section{Women and Transmission of Values}

Values help a person to decide whether preferences or events are good or bad, right or wrong. Values are the basic determiners of opinions, perceptions and attitudes. Value learning is affected by a variety of factors like family, friends and even through personal experience.A child learns values firstly from home; the family members play a major role. Mother is said to be the first teacher for a child and plays a vital role in inculcating values in the child. Family is an important institution that plays a central role in the lives of most of the Indians. Indians remain connected to their parents almost throughout their lives, even grandparents have a special place and major impact. Just as a mother plays an important role in transmission of values, grandmother in many cases plays a superior role.

Sudha Murty in her short stories 'The Red Rice Granary', 'The Rainy Day' and ' $A$ ' for Honesty' reminisces the valuable teachings given to her by her grandmother and mother, and later in her life she understood that her words and actions proved to be valuable lessons for her own son.

Sudha's grandmother Krishtakka gave her a valuable teaching on 'giving' which is still motivating her to give and help others relentlessly. Her grandmother said, 
Child, whenever you want to give something to somebody, give the best in you, never the second best. That is what I have learned from life. God is not there in the temple, mosque or church. He is with the people. If you serve them with whatever you have, you have served God. (Murty, 2004, p. 13)

In India marriage is considered to be a life alternating moment for a girl and usually mothers give some piece of advice to their daughters who are about to get married, similarly Sudha's mother's advice proved to be beneficial to the point that it worked as a seed for the foundation of Infosys. She said,

In life we never know when a rainy day will come and you might fall short of money. In order to be prepared for such a situation, you should always save some money from your salary, and if you are not earning, then from your husband's salary...(Murty, 2004, p. 40)

Sudha accepts that,"When I look back now, I realize that our lives changed completely because I had listened to my mother 's valuable lesson". (Murty, 2004, p. 41)

When Sudha's son got grade "A" in the subject he did not do well he got surprised because he knew he answered a question wrongly. Even though his friends asked him to keep quiet as 'good grades matter', while talking to his mother he accepted, "I thought for a while, then I realized, grades are important but honesty is even more important. You taught me that when I was a little boy..." (Murty, 2004, p. 55)

\section{Women and Education}

The short stories 'How I Taught My Grandmother to Read' and 'The Real Jewels' depict the state of women education in the olden days, the value of education in general and how when a woman understands the significance of education it not only benefits her but also the society.

Sudha's grandmother opens up about her misfortune of being uneducated, and how it makes her feel dependent, yet from her conversation it is clear that she made sure that her children would not suffer the same misfortune. She said,

... In those days people never considered education essential for girls, so I never went to school. I got married very young and had children ... At times I used to regret not going to school, so I made sure that my children and grandchildren studied well ... (Murty, 2004, p. 2)
...I felt so very dependent and helpless. We are well-off, but what use is money when I cannot be independent? (Murty, 2004, p. 2)

Old dear Krishtakka proved what she said,"For a good cause if you are determined, you can overcome any obstacle. I will work harder than anybody but I will do it. For learning there is no age bar". (Murty, 2004, p. 2) And even at the age of sixty-two years she learnt Kannada alphabets.

On the other hand, uneducated Kuttamma made sure to ingrain the worth of education in her son,

'I told my son that in life, the real jewellery is education. The school teacher for whom I worked when I was young used to tell everything will perish over a period of time-flowers, beauty, food. No person looks beautiful forever. But education brings confidence to your face and that is the real beauty.' (Murty, 2004, p. 15-16)

Her determination and efforts to get her son a good education did not go in vain as he himself worked hard and became successful. Even though Aithappa owned many hotels in Bombay he fulfilled his mother's wish to build free schools in villages of South Canara, Karnataka.

The efforts of Kuttamma not only changed the life of her son but her selfless desire to give others what she lacked; jewellery, that is education, proved to be beneficial for the people of the entire district of South Canara. This brought Sudha to the realization that,"It is certainly true that if one man studies, only one person is educated whereas if one lady studies, the entire family is educated". (Murty, 2004, p. 16)

\section{Women and Equality}

Gender inequality refers to discrimination on the basis of gender which leads to unequal access to rights, stereotyped social and cultural roles. Gender equality doesn't mean everybody is or must be equal, rather everybody must have equal opportunities. Gender inequality causes one gender to be privileged over another. Where gender inequality exists, women are usually the sufferers, who are excluded or disadvantaged in relation to decision making and access to economic and social resources.

In short story 'Appro J.R.D.' Sudha Murty talks about her very first experience of gender discrimination, when she came across a job requirement notice from TELCO,

It stated that the company required young, bright engineers, hard working with excellent academic background, etc. 
At the bottom there was a small line: 'Lady candidates need not apply’. (Murty, 2004, p. 19)

Sudha decided to voice against this discrimination and in anger wrote a postcard to JRD Tata which led to an interview call at TELCO Pune. During the interview on of the interview asked Sudha,

Do you know why we said that lady candidates need not apply? The reason is that to this day we have not employed any ladies on the shop floor of the factory. This is an automobile industry. Trainees may have to work in shifts ... All our plants have men and machinery. Our trainees may have to drive. We have a trainee's hostel and a guesthouse for them. If a lady enters, then how we can we accommodate her? We do not know how men on the shop floor will accept her. How will she come for shifts? We care for our employees, particularly if she is a lady. It is not a college where there is no gender difference. This is a factory. When it comes to academics, you are a first ranker throughout. We appreciate that. People like you should work more in research laboratories. (Murty, 2004, p. 20)

To which she answered,

But somewhere you must start. Otherwise, a lady will never be able to work in the factories. You are pioneers in many aspects of life. When I look at your industries, you are far ahead of other people. If you think this way, then how will any lady ever enter this so-called man's domain? (Murty, 2004, p. 20)

The interviewer further added,

Training a candidate costs a lot to our company. You are of a marriageable age. After your training you will leave this company and shift to wherever your husband works. Is it not a waste of money for us? (Murty, 2004, p. 20-21)

Yet again Sudha replied,

I definitely agree with what you say. I am sure when many of you married, your wives came along with you. That has been our tradition. But is it also not true that many men undergo training, and just for a few more hundred rupees, they shift their jobs. You don't have any rule for them. You can't stop them. (Murty, 2004, p. 21)

Sudha successfully secured a job at TELCO and became the first girl to work in TELCO shop-floor. This opportunity given to her by JRD Tata changed her life. She remarks,
Today, in any engineering college I see that forty to fifty per cent of the students are girls. On the shop floor of many mechanical industries, we see so many ladies working. (Murty, 2004, p. 22)

This story is a perfect example of how opportunities given to women equal as men can bring about a massive change which would be beneficial for numerous generations.

\section{Women and Fertility}

Childbearing is considered to be a paramount role of a woman. It is mostly considered to be standard to measure a woman's worth. Infertility takes a toll on the mental andemotional health of a woman as she faces immense family and social pressure.

In India, particularly in villages, even a few decades back, women without children were looked down upon. Such women were not invited for naming ceremonies, and were taunted as barren women. (Murty, 2004, p. 45)

The short story 'Gowramma's Letter' gives us a glimpse of the pain of a woman who suffered infertility and how her own husband and society despised her for it. Women are mostly blamed for infertility and men go in for polygyny to have children. Gowramma shares her pain with Sudha through her letter,

It said, 'I think you know my husband left me long back and everyone used to make fun of me and call me a "barren woman" ... I was always humiliated because I could not bear any children. You know my husband married a second time and had his own children.

(Murty, 2004, p. 46)

This story not only brings the reader to the realization of the pain and suffering of a woman who cannot bear a child but also gives out a message that a woman's worth is in her selfless deeds, values and hard work not in her fertility.

\section{CONCLUSION}

In the book How I Taught My Grandmother to Read and Other Stories by Sudha Murty, the stories 'The Red Rice Granary', 'The Rainy Day' and 'A' for Honesty' brings out the vital role played by women in transmission of values. The stories 'How I Taught My Grandmother to Read' and 'Real Jewels' describe the importance of education in the life of a woman and how a woman can bring a change in the lives of many. While the short story titled 'Appro J.R.D.' brings out the struggleof a woman against gender discrimination and the story 
'Gowramma's Letter' elucidates the pain of an infertile woman.

\section{REFERENCES}

[1] Kangne, R. V., \&Lahane, D. B. T. (2016). The Contribution of Sudha Murthy in Indian English Literature. Epitome Journals, 2(12), 101-109.

[2] Murty, S. (2004). How I Taught My Grandmother to Read and Other Stories (1st ed., Vol. 1). New Delhi, India: Puffin Books.

[3] Times of India. (2017, August 19). Writing is like therapy: Sudha Murty - Times of India. Retrieved from https://timesofindia.indiatimes.com/lifestyle/books/interviews/writing-is-like-therapy-sudhamurty/articleshow/60101933.cms

[4] Vaswani, N. (2021). Sudha Murthy: An Eminent Contributor to Literature. International Journal of English Literature and Social Sciences, 6(1), 109-112. 